\title{
Distribusi dan Pola Segregasi Karakter Kuantitatif F2 Persilangan Padi Situ Patenggang dengan IPB 3S
}

\author{
Distribution and Segregation Patterns of Quantitative Characters on \\ $\mathrm{F}_{2}$ Crossed Rice of Situ Patenggang with IPB $3 S$
}

\author{
A A K Sudharmawan", I G P Muliartha Aryana, Jusmiati \\ Program Studi Agroekoteknologi Fakultas Pertanian, Universitas Mataram \\ Jl. Majapahit 62 Mataram 83125, Telp. (0370) 646506 INDONESIA \\ *corresponding author,email: a_agungk@yahoo.com
}

Manuscript received: 24-10-2019. Accepted: 26-12-2019

\begin{abstract}
ABSTRAK
Penelitian ini bertujuan mengetahui distribusi dan pola segregasi gen yang berperan dalam pewarisan sifat kuantitatif $F_{2}$ hasil persilangan padi Situ Patenggang dengan IPB 3S. Metode yang digunakan dalam penelitian ini adalah metode eksperimental yang dilaksanakan pada bulan Juli sampai Desember 2018 dengan pola tanam single plant. Distribusi data diuji dengan uji Kolmogorov Smirnov menggunakan softwere SPSS 17.0 dan uji kesesuaian nisbah segregasi menggunakan metode ChiKuadrat dengan taraf nyata 5\%. Hasil penelitian menunjukkan karakter jumlah anakan produktif berdistribusi normal dikendalikan oleh banyak gen (polygenic). Karakter tinggi tanaman, jumlah gabah hampa dan jumlah gabah berisi mengikuti pola segregasi Mendel dengan nisbah 15:1 (epistasis dominan ganda; dikendalikan oleh dua gen dominan yang sama-sama epistasis dan mengatur sifat yang sama serta dapat saling menggantikan satu sama lain). Sifat jumlah anakan non produktif, panjang malai, dan berat 1000 butir tidak mengikuti pola nisbah segregasi Mendel atau modifikasinya untuk satu sifat dan dua sifat diasumsikan karena dikendalikan oleh lebih dari dua gen (gen minor) sehingga pengaruhnya secara individu sulit dibedakan.
\end{abstract}

Kata kunci: mendei; pewarisan; tanam tunggal; dominan; epistasis

\begin{abstract}
This study aims to determine the distribution and patterns of gene segregation that play a role in the inheritance of quantitative $F_{2}$ traits resulting from the Situ Patenggang rice crossing with IPB 3S. The method used in this study is an experimental method carried out in July to December 2018 with a single plant cropping pattern. Data distribution was tested by Kolmogorov Smirnov test using SPSS 17.0 software and the suitability of segregation ratio using Chi-Square method with a real level of 5\%. The results showed the nature of the number of productive puppies in normal distribution which means the character is controlled by many genes (polygenic). Plant height, number of empty grains and number of filled grains follow Mendel's segregation pattern with a ratio of 15: 1 (double dominant epistasis; controlled by two dominant genes that are both epistasis and regulate the same traits and can replace one another). the nature of the number of non-productive tillers, panicle length, and weight of 1000
\end{abstract}


grains does not follow the Mendel segregation ratio pattern or its modification for one trait and two traits is assumed because it is controlled by more than two genes (minor genes) so that their individual effects are difficult to distinguish.

Keyword: mendel; inheritance; single; dominan; epistasis

\section{PENDAHULUAN}

Indonesia memiliki daratan luas yang dapat dimanfaatkan untuk pertanian sekitar 188.20 juta ha, terdiri atas 148 juta ha lahan kering (78\%) dan 40.20 juta ha lahan basah (22\%). Lahan kering yang sesuai untuk lahan pertanian mencapai 13.3 juta ha. Lahan tersebut tersebar di wilayah Indonesia bagian tengah termasuk Nusa Tenggara Barat, Nusa Tenggara Timur sampai Papua (Badan Pusat Statistik, 2016).

Menurut Badan Pusat Statistik (2018), wilayah Nusa Tenggara Barat (NTB) terdiri atas dua pulau yaitu pulau Lombok dan pulau Sumbawa yang memiliki luas keseluruhan lahan sawah sekitar 278.011 hektar. Sekitar 276.230 hektar atau sebesar 99.36 \% ditanami padi dan sisanya ditanami tanaman lain. Data pada tahun 2018 menunjukkan masih rendahnya produktivitas padi lahan kering jika dibandingkan dengan padi sawah beririgasi. Produktivitas padi lahan kering hanya sekitar 212.52 ribu ton gabah kering giling (GKG) dengan produktivitas 1.04 ton/ha sedangkan padi sawah beririgasi mencapai 1.904,11 ribu ton gabah kering giling (GKG) dengan produktivitas 8.96 ton/ha.

Salah satu upaya yang dilakukan untuk meningkatkan produktivitas padi lahan kering adalah melalui persilangan antara padi Situ Patenggang x IPB 3S. Kedua varietas padi tersebut masing-masing memiliki kelebihan. Situ Patenggang adalah salah satu varietas padi gogo yang banyak dibudidayakan petani karena memiliki tekstur nasi yang sedang dan bersifat aromatik serta tahan terhadap penyakit blas. Tetapi, produksi Varietas Situ Patenggang tergolong masih rendah sekitar 4.6 sampai 6.0 ton/ha (Hajoeningtijas, 2013). Varietas IPB 3S merupakan varietas padi sawah beririgasi yang juga tahan terhadap kekeringan dengan rata-rata hasil mencapai 7.0 sampai 11.2 ton/ha (Purwono, 2016).

Persilangan akan membentuk keragaman genetik. Salah satu upaya untuk melihat keragaman genetik secara sederhana dapat dilakukan dengan mengamati pola segregasi pada sifat agronomi. Pola segregasi suatu sifat merupakan salah satu parameter genetik yang perlu diketahui dalam hubungannya dengan proses seleksi.

\section{BAHAN DAN METODE}

\section{Waktu, Lokasi dan Bahan Penelitian}

Penelitian ini dilaksanakan di lahan percobaan Fakultas Pertanian Universitas Mataram di Desa Nyiur Lembang Narmada, Kabupaten Lombok Barat, Nusa Tenggara Barat untuk penanaman $F_{2}$ pada bulan Juli sampai Desember 2018. Bahan yang digunakan dalam percobaan ini yaitu benih $\mathrm{F}_{2}$ hasil persilangan padi varietas Situ Patenggang x IPB 3S koleksi Sudharmawan. 


\section{Perlakuan dan Desain Percobaan}

Benih $F_{2}$ ditanam dengan pola single plant, yaitu dengan menanam seluruh populasi $F_{2}$ satu tanaman per lubang tanpa ulangan (1000 tanaman). Jarak tanam yang digunakan adalah 25 x $25 \mathrm{~cm}$ (bujur sangkar).

Penentuan sampel dilakukan secara random sampling, yaitu tanaman sampel diambil secara acak sejumlah 300 sampel dari populasi. Variabel yang diamati dalam percobaan ini adalah sifat kuantitatif yang meliputi: tinggi tanaman $(\mathrm{cm})$, jumlah anakan produktif/rumpun (batang), jumlah anakan non produktif/rumpun (batang), panjang malai (cm), jumlah gabah berisih/malai (butir), jumlah gabah hampa/malai (butir), bobot 1000 butir gabah berisi (g).

\section{Analisis Data.}

Data hasil pengamatan sifat kuantitatif diuji normalitas data dengan uji KolmogorovSmirnov menggunakan softwere SPSS 17.0. Selanjutnya diuji kesesuaian nisbah segregasi menggunakan metode Chi-Kuadrat $(\alpha=5 \%)$. Menurut Gomez \& Gomez (1995) dalam Nugroho et al. (2014) pengujian hipotesis nisbah diuji dengan cara menghitung nilai $\chi^{2}$ tergantung banyaknya kelas. Rumus uji yang digunakan dalam analisis segregasi kesesuaian distribusi normal adalah uji Chi-Kuadrat yaitu sebagai berikut:

a Lebih dari dua kelas

$$
\chi^{2}=\sum_{i=1}^{p} \frac{(n i-E i)^{2}}{E i}
$$
Keterangan:
$\mathrm{p}=$ banyaknya kelas
$\mathrm{ni}$ = banyaknya satuan yang diamati yang termasuk kelas ke-i
Ei = banyaknya satuan yang diharapkan yang termasuk kelas ke-i

b Dua kelas

$$
\chi^{2}=\frac{(|n 1-E 1|-0,5)^{2}}{E 1}+\frac{(|n 2-E 2|-0,5)^{2}}{E 2}
$$

Keterangan:

$\mathrm{n} 1=$ nilai pengamatan kelas ke-1

$\mathrm{n} 2$ = nilai pengamatan kelas ke-2

$\mathrm{E} 1$ = nilai harapan kelas ke-1

$\mathrm{E} 2$ = nilai harapan kelas ke-2

Nilai hitung dibandingkan dengan taraf nyata 5\% $(0,05)$, bila $\chi^{2}$ hitung $<\chi^{2}$ tabel maka sifat yang dianalisis berdistribusi normal, sebaliknya $\chi^{2}$ hitung $>\chi^{2}$ tabel maka sifat yang dianalisis tidak berdistribusi normal. 


\section{HASIL DAN PEMBAHASAN}

Hasil uji normalitas data pada Tabel 1 menunjukkan bahwa dari sebaran frekuensi data kuantitatif untuk sifat tinggi tanaman, jumlah anakan non produktif, panjang malai, gabah berisi, gabah hampa dan berat 1000 butir terdistribusi tidak normal, sedangkan untuk sifat jumlah anakan produktif terdistribusi normal. Carsono et al. (2014) mengatakan jika sebaran data tidak normal maka perlu dilakukan uji Chi-Kuadrat untuk mengetahui pola segregasi Mendel atau modifikasinya yang tepat. Sifat yang tidak terdistribusi normal dapat mengikuti rasio fenotipe Mendel

Tabel 1. Hasil uji normalitas data kuantitatif $F_{2}$ dengan uji Kolmogorov-Smirnov

\begin{tabular}{lrrrrrrr}
\hline & \multicolumn{1}{c}{ TT } & JAP & JANP & PM & JGB & JGH & B1000 \\
\hline $\mathrm{N}$ & \multicolumn{1}{c}{300} & 300 & 300 & 300 & 300 & 300 & 300 \\
Normal Parameter & & & & & & & \\
$\quad$ Mean & 935.267 & 255.400 & .7900 & 266.170 & 1.280 .267 & 83.500 & 275.700 \\
$\quad$ Std. Deviation & 1.095 .701 & 670.409 & 111.806 & 171.273 & 2.530 .865 & 342.343 & 235.306 \\
Most Extreme & & & & & & & \\
Difference & & & & & & & \\
$\quad$ Absolute & .259 & .077 & .307 & .123 & .137 & .161 & .191 \\
$\quad$ Positive & .259 & .077 & .307 & .122 & .137 & .161 & .152 \\
$\quad$ Negative & -.137 & -.064 & -.240 & -.123 & -.117 & -.082 & -.191 \\
Kolmogorov-Smirnov Z & 4.485 & 1.331 & 5.313 & 2.125 & 2.378 & 2.795 & 3.308 \\
Asymp. Sig. (2-tailed) & .000 & .058 & .000 & .000 & .000 & .000 & .000 \\
\hline
\end{tabular}

Keterangan: $\mathrm{TT}=$ Tinggi tanaman, $\mathrm{JAP}=\mathrm{Jumlah}$ anakan produktif, JANP $=$ Jumlah anakan non produktif, $\mathrm{PM}=$ Panjang malai, JGB= Jumlah gabah berisi, JGH= Jumlah gabah hampa, $\mathrm{B} 1000=$ Berat 1000 butir.

Tabel 2. Hasil uji Chi-Kuadrat sifat kuantitatif $\mathrm{F}_{2}$ Varietas Situ Patenggang x IPB 3S

\begin{tabular}{lccc}
\hline \multicolumn{1}{c}{ Sifat } & Nisbah Segregasi & $\chi^{2}$ hitung & $\chi^{2}$ tabel 5\% \\
\hline Tinggi tanaman & $15: 1$ & 0,83 & 3,841 \\
Jumlah anakan non produktif & - & - & - \\
Panjang malai & - & - & - \\
Jumlah gabah berisi & $15: 1$ & 1,28 & 3,841 \\
Jumlah gabah hampa & $15: 1$ & 2,59 & 3,841 \\
Berat 1000 butir & - & - & - \\
\hline
\end{tabular}

Hasil uji Chi-Kuadrat (Tabel 2.) menunjukkan sifat tinggi tanaman, jumlah gabah berisi, dan jumlah gabah hampa memiliki nilai $\chi^{2}$ hit $<\chi^{2}$ tabel pada taraf nyata $5 \%$. Sifat-sifat tersebut mengikuti nisbah modifikasi Mendel, yaitu 15: 1 (epistasis dominan ganda). Sedangkan sifat jumlah anakan non produktif, panjang malai, dan berat 1000 butir tidak mengikuti pola segregasi nisbah Mendel maupun modifikasinya. 


\section{Sifat-sifat yang mengikuti nisbah Mendel}

Sifat tinggi tanaman, berdasarkan hasil uji Chi-Kuadrat untuk penyesuaian nisbah Mendel menunjukkan bahwa fenotipe sifat tinggi tanaman pada $F_{2}$ hasil persilangan padi Situ Patenggang $x$ IPB 3S mengikuti nisbah segregasi $15: 1$. Gen pengendalian sifat tinggi tanaman terdiri atas dua gen yang bekerja secara epistasis dominan ganda. Epistasis dominan ganda merupakan peristiwa yang disebabkan dua gen dominan sama-sama epistasis dan mengatur sifat yang sama serta dapat saling menggantikan satu sama lain.

Berdasarkan hasil uji normalitas jumlah anakan non produktif menunjukkan bahwa sifat jumlah anakan produktif memiliki sebaran data terdistribusi normal. Menurut hasil penelitian Carsono et al. (2014) yang dilakukan pada kandungan amilosa tanaman padi populasi $\mathrm{F}_{2}$ persilangan Ciherang $\mathrm{x}$ Basmati terdistribusi normal yang berarti sifat tersebut dikendalikan secara polygenic. Sriwidarti (2011) menambahkan pada hasil penelitian tanaman kacang panjang menunjukkan bahwa sifat jumlah polong per tanaman dan bobot 100 butir merupakan sifat kuantitatif yang mengikuti sebaran normal yang dikendalikan oleh banyak gen (polygenic). Menurut Allard (1995) sebaran frekuensi yang dikendalikan secara polygenic termasuk sifat kuantitatif. Dengan demikian sifat jumlah anakan produktif pada hasil penelitian termasuk dalam sifat kuantitatif yang dikendalikan secara polygenic sehingga tidak perlu dilakukan pengujian nisbah Mendel karena sebaran data berdistribusi normal.

Jumlah gabah berisi pada hasil uji kesesuaian nisbah segregasi sifat jumlah gabah berisi mengikuti nisbah $15: 1$. Sifat tersebut disebabkan karena dua gen dominan sama-sama epistasis dan mengatur sifat yang sama dan dapat menggantikan satu sama lain. Epistasis dominan ganda merupakan sifat hasil yang dikendalikan oleh banyak gen (polygenic). Crowder (1988), mengatakan bahwa sifat kuantitatif seperti daya hasil, jumlah biji, tinggi tanaman, umur panen berat kering biji dikendalikan oleh banyak gen yang dalam penampilannya dipengaruhi oleh faktor lingkungan dan interaksi antar gen. Sifat kuantitatif tanaman tidak diwariskan secara sederhana seperti pada sifat kualitatif. Sifat kuantitatif ditentukan oleh satu atau dua gen dan pengaruh lingkungan kecil terhadap penampakan sifat, sehingga diperlukan dalam jumlah yang cukup banyak dan masing-masing gen bersifat aditif.

Jumlah gabah hampa, sifat ini mengikuti nisbah $15: 1$. Hasil uji Chi-Kuadrat penyesuaian nisbah menunjukan $\chi^{2}$ hit $(2.59)$ lebih kecil dibandingkan nilai $\chi^{2}$ tabel $(3,814)$ untuk dua sifat beda. Nisbah $15: 1$ diartikan bahwa sifat jumlah gabah hampa dikendalikan oleh gen yang bersifat epistasis dominan ganda. Epistasis dominan ganda merupakan keadaan dimana dua gen dominan sama-sama epistasis dan mengatur sifat yang sama serta dapat saling menggantikan satu sama lain.

\section{Sifat-sifat yang tidak mengikuti nisbah Mendel}

Sifat jumlah anakan non produktif, panjang malai, dan berat 1000 butir tidak mengikuti nisbah Mendel atau modifikasinya. Sifat-sifat tersebut dikendalikan oleh banyak gen. Menurut Baihaki (2000), pada sifat kuantitatif masing-masing gen mempunyai kontribusi kecil dalam pewarisan suatu sifat, sehingga efek-efek individunya tidak bisa dideteksi oleh metode Mendel. 
Berdasarkan hasil uji Chi-Kuadrat untuk penyesuaian nisbah menunjukkan sifat jumlah anakan non produktif, panjang malai, dan berat 1000 butir dikendalikan oleh lebih dari dua gen sehingga pengaruhnya secara individu sulit dibedakan. Menurut Ambarwati (2014), perbedaan gen pada banyak lokus menentukan pewarisan sifat kuantitatif.

Hasil analisis pada data sifat jumlah anakan non produktif, panjang malai, dan berat 1000 butir terdapat perbedaan baik pada hasil uji normalitas maupun pada uji pola pewarisan. Hasil analisis menunjukkan terdapat ketidaksesuain antara hasil dua uji yang digunakan. Hal ini dimungkinkan akibat tidak terwakilinya semua genotipe $F_{2}$ yang diamati. Menurut Sudharmawan (2009), ketidaksesuaian diduga disebabkan karena gen yang mengendalikan sifat-sifat tersebut lebih dari dua gen.

Berat 1000 biji termasuk sifat kuantitatif yang dikendalikan oleh banyak gen, masingmasing gen berpengaruh kecil terhadap ekspresi suatu sifat (Trustinah, 1997). Menurut Ambarwati (2014), sifat kuantitatif berbeda dengan sifat kualitatif dimana gen mayor cenderung lebih banyak berperan dalam mengendalikan sifat kualitatif dan banyaknya pengendali adalah monogenik. Sifat kuantitatif memperlihatkan variasi kontinu yang dikendalikan oleh banyak gen, masing-masing gen secara individu berpengaruh kecil, tetapi cara kerjanya serupa dan akan bersifat kumulatif apabila bekerja bersama-sama.

\section{KESIMPULAN}

Sifat jumlah anakan produktif $\mathrm{F}_{2}$ hasil persilangan Situ Patenggang x IPB $3 \mathrm{~S}$ terdistribusi normal, yang berarti sifat tersebut dikendalikan oleh banyak gen (polygenic). Pola segregasi sifat kuantitatif yakni: tinggi tanaman, jumlah gabah hampa dan jumlah gabah berisi mengikuti pola segregasi Mendel, dengan nisbah fenotipe 15:1 (epistasis dominan ganda = dikendalikan oleh dua gen dominan yang sama-sama epistasis dan mengatur sifat yang sama serta dapat saling menggantikan satu sama lain). Sifat kuantitatif jumlah anakan non produktif, panjang malai, dan berat 1000 butir tidak mengikuti pola segregasi Mendel atau modifikasinya untuk satu sifat atau dua sifat, diasumsikan karena dikendalikan oleh lebih dari dua gen sehingga pengaruhnya secara individu sulit dibedakan.

\section{DAFTAR PUSTAKA}

Allard, R. W. 1995. Pemuliaan Tanaman Jilid II (Terjemahan dari Principles of Plant Breeding). Penerbit. PT Rineka Cipta. Jakarta.

Ambarwati. E. 2014. Pengantar Genetika Kuantitatif. Gadjah Mada University Press. Yogyakarta.

Badan Pusat Statistik (BPS) Nusa Tenggara Barat. 2016. Luas Lahan menurut Penggunaan Provinsi Nusa Tenggara Barat. Balai Pusat Statistik. Mataram

Badan Pusat Statistik (BPS). 2018. Luas Panen dan Produksi Padi di Provinsi Nusa Tenggara Barat. 2018.

Baihaki, A. 2000. Teknik Rancang dan Analisis Penelitian Pemuliaan. Universitas Padjajaran. Diktat mata kuliah: Bandung. $91 \mathrm{hlm}$. 
Carsono, N., Ranggi Eldikara, Santika Sari, Farida Damayanti, dan Meddy Rachmadi. 2014. Pola Segregasi Pewarisan Sifat Butir Kapur dan Kandungan Amilosa Beras pada Generasi F Beberapa Hasil Persilangan Padi (Oryza sativa L.). Fakultas Pertanian. Universitas Padjajaran. Bandung. Chimica et Natura Acta 2 (2):131-136.

Crowder, L. V. 1988. Genetika Tumbuhan (Terjemahan dari Plant Genetics). Gajah Mada University Press. Yogyakarta.

Gomez, A. K., dan A. A. Gomez. 1995. Prosedur Statistik untuk Penelitian (Terjemahan dari Statistical Prosedures for Agriculture Research). Penerbit. Universitas Indonesia. 313 hlm.

Hajoeningtijas, O.D., 2013. Keragaman Padi Gogo Lokal di Kabupaten Banyumas Jawa Tengah. Fakultas Pertanian Universitas Purwokerto. Agritech: Vol. XV No. 22013.

Millah, Z., Sriani Sujiprihati, dan Sri Hendrastuti Hidayat. 2012. Pewarisan Sifat Ketahanan Terhadap CHIVMV (Chilli Veinal Mottle Virus) Pada Tanaman Cabai. Jurusan Agroekoteknologi Fakultas Pertanian Untirta. Jurnal Agroekotek 4 (1): 47-54.

Nugroho, W. P., Maimun Barmawi, dan Nyimas Sa'diyah. 2013. Pola Segregasi Sifat Agronomi Tanaman Kedelai (Glycine max [L.] Merill) Generasi F2 Hasil Persilangan Yellow Bean dan Taichung. Jurusan Agroteknologi Fakultas Pertanian Universitas Lampung. Jurnal Agrotek Tropika. 1 (1): 38 - 44.

Purwono, 2016. Kelebihan Varietas IPB 3 S. Focus Group Discussion Inovasi IPB. Diakses melalui http://m.detik.com/finance/berita-ekonomi-bisnis. [10 November 2018].

Sriwidarti. 2011. Pola Pewarisan Sifat Kualitatif dan Kuantitatif Kacang Panjang Keturunan Testa Coklat x Testa Hitam. Tesis. Unila. Bandar Lampung. 105 hlm.

Sudharmawan, A. A. K. 2009. Kajian Tindak Gen Ketahanan Terhadap Cekaman Kekeringan pada Akar Padi Beras Merah. [Disertasi, unpublished]. Program Pasca Sarjana Fakultas Pertanian, Univerasitas Gadjah Mada. Yogyakarta.

Trustinah. 1997. Pewarisan Beberapa Sifat Kuantitatif dan Kualitatif pada Kacang Tunggak (Vigna unguiculata L Walp). Penelitian pertanian tanaman pangan. 15 (2): 48-5 